Dept. of Obstetrics.

Fac. Vet. Med., University of Alexandria

\title{
CHANGES IN SERUM PROGESTERONE PATTERNS DURING THE SHORT LUTEAL CYCLES INITIATED AFTER CALVING AND RELATIONSHIP TO CONCEPTION IN BUFFALO-COWS
}

(With 3 Tables and 1 Figure)

\author{
By \\ W.M.B. NOSEIR \\ (Received at 15/9/1999)
}

\section{التغيرات في مستوى هزمون البزوجيستيزون خلال الدورات الليوتينية القصيرة بعد الولادة وعلاقتها بالحمل في إناث الجاموس فئس}

\section{وائل محد بهجت}

تم دراسة التغيرات في هرمون البروجيستيـرون في عشــرة من إناث الجاموس خال الفـترة

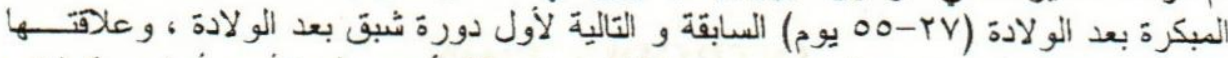

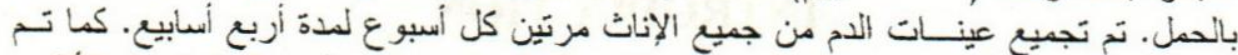

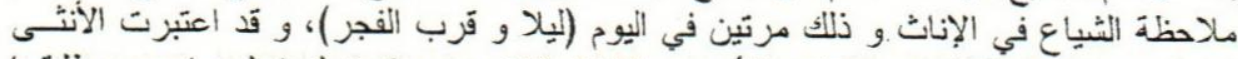

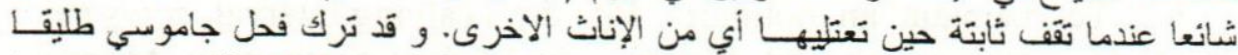

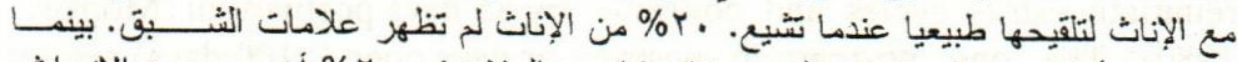

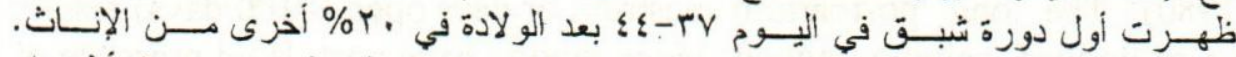

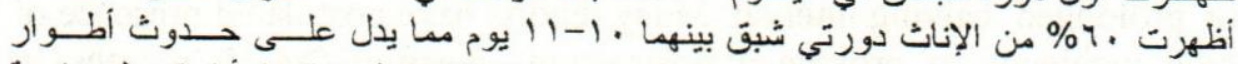

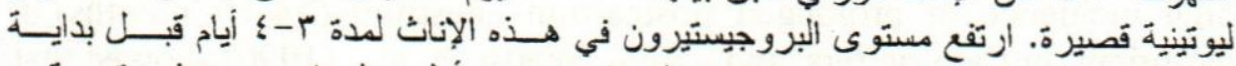

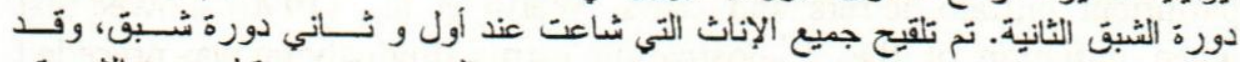

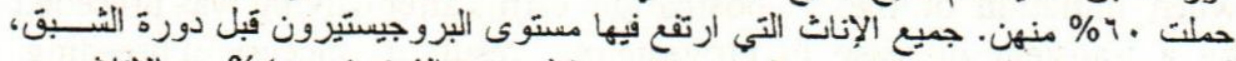

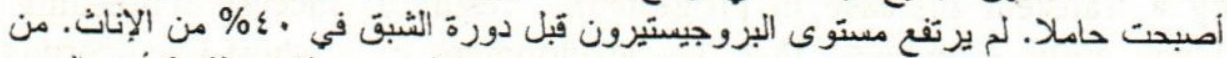

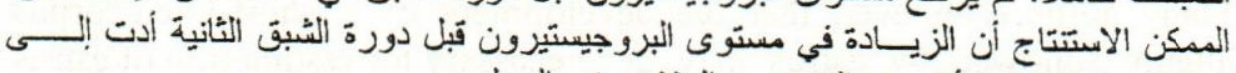

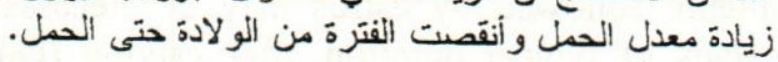

\section{SUMMARY}

Serum progesterone patterns were assessed in 10 parturient buffalo-cows during the early postpartum period (27-55 days) preceding and 
succeeding $1^{\text {st }}$ estrus after calving, and their relation to conception. Blood samples were collected from all buffalo-cows twice weekly for 4 weeks. Estrus was observed in all buffalo-cows twice daily (late evening and at dawn), and were considered to be in estrus when they stood to be mounted by other buffalo-cows. A fertile buffalo-bull was left free with buffalo-cows for natural service. $20 \%$ of buffalo-cows had no estrus cycles. Two (20\%) buffalo-cows showed the first postpartum estrus at day $37-44$ postpartum. $60 \%$ of buffalo-cows $(n=6)$ exhibited 2 heats with interestrus interval ranging between 10 and 11 days indicating occurrence of short luteal periods. These buffalo-cows had a transient increase in progesterone 3-4 days before the $2^{\text {nd }}$ postpartum estrus. All estrus buffalo-cows were bred at $1^{\text {st }}$ and $2^{\text {nd }}$ heat, and $60 \%$ conceived at the latter estrus. All buffalo-cows that had a transient increase in progesterone before estrus became pregnant. $40 \%$ of buffalo-cows had no transient progesterone increase before estrus. It could be concluded that the transient increase in progesterone before the $2^{\text {nd }}$ postpartum estrus, increases conception rate and reduces calving-conception interval.

Key words: Serum Progesterone Patterns In Buffalo-cows

\section{INTRODUCTION}

To maintain an optimum 365 days calving interval, cows must reinitiate estrus cycles and conceive by 85 days postpartum (Morrow, 1980 ). The long postpartum anestrum or days open (>100 days) results in prolonged calving interval. Many reports have postulated presence of high incidence of prolonged postpartum anestrum ( $>4-10$ months) in parturient buffalo-heifers and cows. Werth et al. (1996) showed that when initiation of the $1^{\text {st }}$ postpartum estrus after calving was preceded by a transient increase in progesterone result in successful breeding. Many authors believed that the development of a short-lived corpus luteum followed by estrus may be necessary for resumption of estrus cycles of typical duration after calving (Odde et al., 1980; RomirezGodinez et al., 1981 and Pratt et al., 1982). Anderson and Day (1998) concluded that feeding Melengestrol acetate and injection of progesterone during early postpartum period are capable of inducing fertile estrus after calving in cows. Therefore, the influence of transient increase in progesterone and/or presence of short luteal phase on 
resumption of the $1^{\text {st }}$ postpartum manifested estrus and relationship to conception in buffalo-cows has not been investigated. The aim of this study is to access the changes in serum progesterone patterns during early postpartum period preceding and succeeding $1^{\text {st }}$ estrus after calving and their relation to conception when breeding occurred at this estrus.

\section{MATERIAL and METHODS}

Serum progesterone patterns associated with the initiation of the first manifested estrus after calving were assessed in 10 parturient buffalo-cows ( 3 primiparous and 7 pluriparous buffalo-cows). The animals belonged to small animal owners in Behaira province. The age range varied between 3-6 years. All buffalo-cows were in early postpartum period between 27 and 55 days (4 weeks) post calving. Parturitions were between December and March. All buffalo-cows gave normal births with normal live calves. Calves were allowed for free suckling program with their mothers. Milk production varied between 3$5 \mathrm{~kg}$ /day. Feeding depended mainly on barseem (Trifolium alexandrinum) and/or hay, together with mineral supplement. Blood samples were collected by jugular venipuncture twice weekly for 4 weeks starting from day 27 to day 55 postpartum. Serum was separated and stored at $-20^{\circ} \mathrm{C}$ until analyzed for progesterone assay using RIA kits (Diagnostic Products Corporation, USA).

All buffalo-cows were subjected to thorough estrus observation twice daily (late evening and dawn), by the owners who were trained for detecting the true signs of estrus. Buffalo-cows were considered to be in estrus when they stood to be mounted by other buffalo-cows. A fertile buffalo-bull was left free with parturient buffalo-cows for natural service at the owner's place. Pregnancy diagnosis was carried out rectally, 60 days post service.

\section{RESULTS}

Results are obtanied at Tables 1, 2 \& 3 and Figure 1. 


\section{DISCUSSION}

Serum progesterone concentrations during 27 to 55 days postpartum, are presented in Table 1 . The concentration varies between $0.11 \mathrm{ng} / \mathrm{ml}$ at day 27 postpartum, to $1.03 \mathrm{ng} / \mathrm{ml}$ at day 55 . Two $(20 \%)$ out of 10 buffalo-cows showed the first postpartum estrus 37-44 days postpartum. $60 \%$ of buffalo-cows $(n=6)$ exhibited 2 heats with interestrus interval ranging between 10 and 11 days (Table, 2 \& Fig. 1) indicating occurrence of short luteal periods. $60 \%$ of buffalo-cows had a transit increase in progesterone (1.27-1.40 ng/ml) 3-4 days before estrus (Table, 3). All estrus buffalo-cows were bred at $1^{\text {st }}$ and $2^{\text {nd }}$ heat (after short interestrus interval) and $60 \%$ conceived at the latter estrus. All buffalo-cows that had a transient increase in progesterone before estrus became pregnant, this transient increase in progesterone was first shown at 44-55 days postpartum (Table, 3). Buffalo-cows that had no transient progesterone increase before estrus $(40 \%)$ failed to conceive.

The source of the transient increase in progesterone is possibly due to the presence of short-lived corpus luteum or luteinized ovarian follicle. Similar postulates were reported by Donaldson et al. (1970), Corah et al. (1979) and Werth et al. (1996). Y' Yiich et al. (1997) suggested presence of a persistent dúminant luteinized follicle during early postpartum period âfter calving. Anderson and Day (1998) concluded that adininistration of progesterone during early postpartum period indruced acute increase in progesterone before resumption of the first postpartum fertile estrus.

The transient increase in progesterone that occurred before $1^{\text {st }}$ estrus after calving and its relation to conception may possibly have a role in preparation of the reproductive tract of buffalo-cows for pregnancy. Similar findings were reported by Werth et al. (1996). Kinder et $\underline{\text { al }}$. (1995) found similar increase in progesterone preceding pubertal estrus of heifers and hypothesized that this increase serve for providing a more desirabie uterine environment that made conception positive as a result of mating at the pubertal estrus.

It is nossible to say that this transient increase in progesterone prior to $i^{\text {si }}$ postpartum fertile service increases conception rate and in turn reduces the calving-conception interval. 


\section{REFERENCES}

Anderson, L.H., and Day, M.L. (1998): Development of progestin-based estrus synchronization program: 1. Reproductive response of cows fed melengestrol acetate for 20 days with an injection of progesterone. J. Anim. Sci., 76(5): 1267.

Corach, L.R., Quealy, A.P., Dunn, T.G., and Kaltenbach (1979): Prepartum and postpartum levels of progesterone and estradiol in beef heifers fed two levels of energy. J. Anim. Sci., 39: 380.

Donaldson, L.E., Bassett, J.M., and Thorburn, G.D. (1970): Peripheral plasma progesterone concentration of cows during puberty and the effects of under nutrition or exogenous oxytocin on progesterone concentration. J. Endocrinol. 48: 599.

Kinder, J.E., Bergfeld, E.G.M., Wehrman, M.E., Peters, K.E., and Kojima, F.K. (1995): Endocrine basis of puberty in heifers and ewes. Reproduction in Domestic Ruminants. III. J. Reprod. Fert. Suppl. 49, 393.

Morrow, D.A. (1980): Current Therapy in Theriogenology. W.B. Saunders Company, London.

Odde, K.G., Ward, H.S., Kiracofe, G.H., McKee, R.M., and Kittok, R.J. (1980): Short estrus cycles and associated serum progesterone levels in beef cows. Theriogenology, 14, 102.

Pratt, B.R., Berardinelli, J.G., Stevens, L.P., and Inskeep, E.K. (1982): Induced corpora lutea in the postpartum beef cow. I. Comparison of $\mathrm{GnRH}$ and $\mathrm{HCG}$ and effects of progesterone and estrogen. J. Anim. Sci., 54: 822.

Romirez-Godinez, J.A., Kiracofe, G.H., McKee, R.M., Schalles, R.R., and Kittok, R.J. (1981): Reducing the incidence of short luteal cycles in beef cows with Norgestomet. Theriogenology, 15: 613.

Werth, L.A., Whittier, J.C., Azzam, S.M., Deutscher, G.H. and Kinder, J.E. (1996): Relationship between circulating progesterone and conception at first postpartum estrus in young primiparous beef cows. J. Anim. Sci., 74: 616.

Yelich, J.V., Geisert, R.D., Schmitt, R.A., Morgan, G.L., and McCann, J.P. (1997): Persistence of the dominant follicle during melengestrol acetate administration and its regression by estrogen treatment in beef cattle. J. Anim. Sci., 75(3): 745. 
Table [1]: Serum progesterone patterns and incidence of estrus in parturient buffalocows

\begin{tabular}{|c|c|c|c|}
\hline \multirow{2}{*}{ Days postpartum } & $\begin{array}{c}\text { Serum progesterone } \\
(\mathrm{ng} / \mathrm{ml})\end{array}$ & \multicolumn{2}{|c|}{ Buffalo-cows in estrus } \\
\cline { 3 - 4 } & 0.11 & No. & $\%$ \\
\hline 27 & 0.65 & -- & -- \\
\hline 30 & 0.89 & -- & - \\
\hline 34 & 0.71 & 2 & 20 \\
\hline 37 & 0.97 & 2 & 20 \\
\hline 41 & 0.99 & 3 & 30 \\
\hline 44 & 1.20 & 2 & 20 \\
\hline 48 & 1.03 & 3 & 30 \\
\hline 51 & 1.03 & 3 & 30 \\
\hline 55 & & & \\
\hline
\end{tabular}

Table [2]: The incidence of postpartum short luteal cycles in buffalo-cows

\begin{tabular}{|c|c|c|c|c|c|c|c|c|c|}
\hline \multirow{3}{*}{$\begin{array}{l}\text { No. of buffalo- } \\
\text { cows }\end{array}$} & \multicolumn{6}{|c|}{ Buffalo-cows having short cycles } & \multirow{3}{*}{$\begin{array}{l}\text { Interestrus } \\
\text { interval } \\
\text { (days) }\end{array}$} & \multicolumn{2}{|c|}{$\begin{array}{l}\text { Pregnancy } \\
\text { rate }\end{array}$} \\
\hline & \multicolumn{2}{|c|}{1 cycle } & \multicolumn{2}{|c|}{2 cycles } & \multicolumn{2}{|c|}{ Non } & & & \\
\hline & No. & $\%$ & No. & $\%$ & No. & $\%$ & & No. & $\%$ \\
\hline 10 & 2 & 20 & 6 & 60 & 2 & 20 & \multirow[b]{2}{*}{$10-11$} & \multirow[b]{2}{*}{6} & \multirow[b]{2}{*}{60} \\
\hline $\begin{array}{c}\text { Mean serum } \\
\text { progesterone } \\
\text { concentration } \\
(\mathrm{ng} / \mathrm{ml})\end{array}$ & \multicolumn{2}{|c|}{$1.01 \pm 0.67$} & \multicolumn{2}{|c|}{$0.62 \pm 0.48$} & \multicolumn{2}{|c|}{$1.35 \pm 0.64$} & & & \\
\hline
\end{tabular}


Table [3]: The incidence of transient increase in progesterone previous to estrus in parturient buffalo-cows

\begin{tabular}{|c|c|c|c|c|c|}
\hline \multirow[t]{2}{*}{$\begin{array}{l}\text { No. of buffalo- } \\
\text { cows }\end{array}$} & \multicolumn{2}{|c|}{$\begin{array}{c}\text { Buffalo-cows } \\
\text { showed } \\
\text { transient } \\
\text { progesterone } \\
\text { increase }\end{array}$} & \multirow[t]{2}{*}{$\begin{array}{l}\text { Level of } \\
\text { transient } \\
\text { progesterone } \\
\text { increase } \\
(\mathrm{ng} / \mathrm{ml})\end{array}$} & \multirow[t]{2}{*}{$\begin{array}{l}\text { Onset of the } \\
\text { increase (days } \\
\text { postpartum) }\end{array}$} & \multirow[t]{2}{*}{$\begin{array}{c}\text { Days of } \\
\text { increase before } \\
\text { estrus }\end{array}$} \\
\hline & No. & $\%$ & & & \\
\hline 10 & 6 & 60 & $1.27-1.40$ & $44-55$ & $3-4$ \\
\hline
\end{tabular}
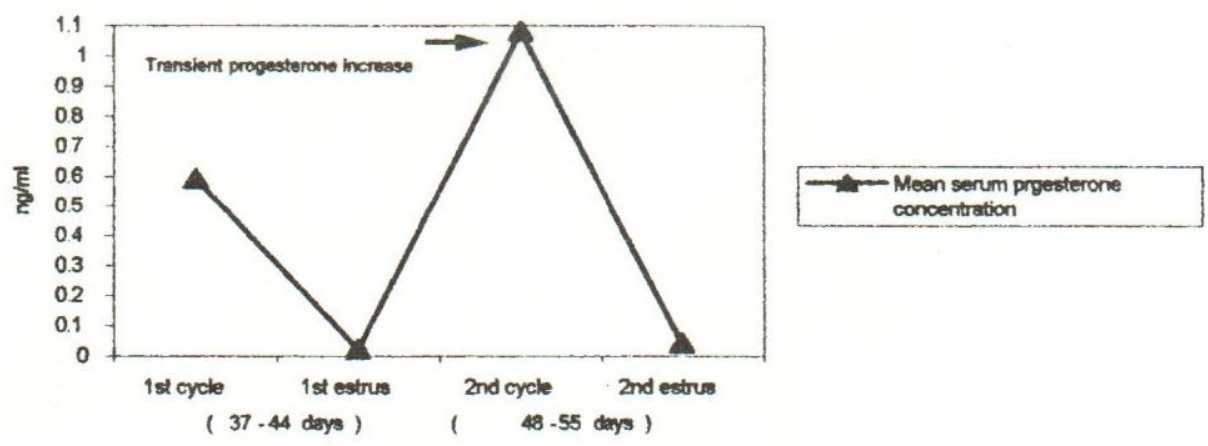

Fig.[1]: Mean serum progesterone concentration in parturient buffalo-cows $(n=6)$ with 2 short huteal cycles 
